\title{
Lead, Cadmium and Nickel Accumulation in Some Common Spices Grown in Industrial Areas of Bangladesh
}

\author{
H. M. Naser ${ }^{1}$, S. Sultana ${ }^{1}$, M. Manjurul Haque ${ }^{2}$, S. Akhter ${ }^{1}$ and R. A. Begum ${ }^{1}$ \\ ${ }^{1}$ Soil Science Division, Bangladesh Agricultural Research Institute, Gazipur-1701, Bangladesh \\ ${ }^{2}$ Department of Bioenvironmental Science, Bangabandhu Sheikh Mujibur Rahman Agricultural \\ University, Gazipur-1706, Bangladesh
}

*Corresponding author and Email: nasemh2@yahoo.com

Received: 6 October 2013 Accepted: 14 June 2014

\begin{abstract}
Chemical analysis was conducted to determine the contents of lead $(\mathrm{Pb})$, cadmium $(\mathrm{Cd})$ and nickel $(\mathrm{Ni})$ of three common spices viz, onion (Allium cepa), garlic (A. sativum) and chilli (Capsicum annuum) and their rhizospheric soils grown in polluted and non-polluted areas of Gazipur city in Bangladesh. Plant and rhizospheric soil samples were collected from: (i) directly polluted (Kaliakoir, Konabari, Gazipur), (ii) indirectly polluted (Donker bill, East Kaliakoir, Konabari, Gazipur), and iii) non-polluted (Bangladesh Agricultural Research Institute, Joydebpur, Gazipur) areas. Regardless of the locations, there were significant differences $(P \leq 0.01)$ in $\mathrm{Pb}, \mathrm{Cd}$, and $\mathrm{Ni}$ concentrations in all spices and soils. The concentrations of $\mathrm{Pb}, \mathrm{Cd}$ and $\mathrm{Ni}$ were in the order of $\mathrm{Ni}>\mathrm{Pb}>\mathrm{Cd}$ in the spices and degrees of pollution in soils were in the order of directly polluted>indirectly polluted $>$ non-polluted area. The $\mathrm{Pb}, \mathrm{Cd}$ and $\mathrm{Ni}$ contents were found higher in garlic followed by chilli and onion in three areas. Most of the metals were accumulated in bulb/fruit, moderate in root and the smallest in the leaf. Compared to the nonpolluted area, the higher amount of $\mathrm{Pb}, \mathrm{Cd}$ and $\mathrm{Ni}$ were detected in both soils and spices samples collected around industrial areas of Gazipur city. Alarmingly, all the spices contained $\mathrm{Pb}, \mathrm{Cd}$, and $\mathrm{Ni}$ were higher than the tolerance limits proposed by Food and Agricultural Organization (FAO)/World Health Organization (WHO) and State Environmental Protection Administration (SEPA). Therefore, it is strongly recommended not to grow spice crops in polluted areas.
\end{abstract}

Keywords: Heavy metal accumulation, spice, soil, polluted area, non-polluted area

\section{Introduction}

Contamination of environment with toxic heavy metals is one of the major concerns in the world. Generally, most of the heavy metals are extremely toxic because of their nonbiodegradable nature, long biological half-lives and their solubility in water (Jarup, 2003). Heavy metals in surface water bodies, ground water and soils can be either from natural or anthropogenic sources. Sources of anthropogenic metal contamination in soils include urban and industrial wastes; mining and smelting of non ferrous metals and metallurgical industries (Singh, 2001). Other sources of anthropogenic contamination include the addition of manures, sewage sludge, fertilizers and pesticides to soils (Whatmuff, 2002; McBride, 2003). Currently, anthropogenic inputs of metals exceeded the natural inputs due to increased urbanization and industrialization. In urban and peri urban areas, land contamination with toxic metals is common as a result of industrial and municipal activities. 
Heavy metal accumulation in soil is of major concern in agricultural production due to the adverse effects on food quality, crop growth and soil environmental health (Ma et al., 1994). Heavy metal accumulation in the food chain possesses serious negative impact to human health (Khan et al., 2008; Mahmood and Malik, 2014). Heavy metals are easily accumulated in the edible parts of leafy vegetables compared to grain or fruit crops (Mapanda et al., 2005). Vegetables up take heavy metals and accumulate them in their edible and inedible parts in quantities high enough to cause clinical problems both to animals and human beings consuming these metal-rich plants (Arora et al., 2008; Alam et al., 2003; Bahemuka and Mubofu, 1991). Heavy metals accumulation by plants depends on plant species (Mattioni et al., 1997) and soil properties (Bruemmer et al., 1986). Plants growing nearby the zone of industrial areas display increased concentration of heavy metals, serving in many cases as biomonitors of pollution loads (Mingorance et al., 2007).

In Bangladesh, people generally consume large amount of spices. Different types of spices are grown well in Gazipur district of Bangladesh but it is quite rich by several types of industries. These industries discharge untreated wastewaters containing various types of hazardous chemicals including enzymes, detergents, dyes, acids, alkalies, salts and toxic heavy metals (Roy et al., 2009). Besides, generally industrial effluent has the characteristics of high amount of total dissolved solid (TDS), high biological oxygen demand (BOD) and chemical oxygen demand (COD) (Roy et al., 2009). All the rivers, canals, and water bodies are being polluted due to discharge of industrial effluents, sewage sludge and municipal wastewaters. After receiving a huge flux of industrial effluents, sewage sludge and municipal wastes, the drainage pass the wastewaters from urban area to sub urban areas and finally into the river Turag. Cultivation of spices with the industrial and sewage effluents is a common practice in studied area. Generally, local farmers across the river Turag use surface wastewater to irrigate their agricultural fields for cultivation of spices. Thus, spices grown on irrigation with wastewaters or soils contaminated with industrial effluents may accumulate toxic heavy metals.. So far, heavy metals in common spice grown in polluted areas of Bangladesh were not reported. However, this information is urgently needed for the production of quality spice as well as healthy food stuffs. Therefore, the present study was undertaken with an aim to determine the concentrations of heavy metals such as lead, cadmium and nickel in commonly grown spices (onion, garlic and chilli) in polluted areas of Gazipur in Bangladesh.

\section{Materials and Methods \\ 2.1. Sampling}

Soils and spices viz. onion (Allium cepa), garlic (A. sativum) and chilli (Capsicum annuum) samples were collected from three agricultural areas exposed to different degrees of pollutions. The area 1 (Kaliakoir, Konabari, Gazipur) is directly polluted by irrigation from the river Turag. Turag is highly polluted due to discharge of industrial effluents, sewage sludge, municipal wastewater and urban pollutants. The area 2 (Donkar bill, East Kaliakoir, Gazipur) is indirectly polluted by ponds and canals water which is contaminated by industrial effluents, sewage sludge and municipal wastewater. During the rainy season, ponds and canals are overflowed by rain water and submerged the adjacent cultivable land where the farmers grown their crops in winter. The area 3 is the Bangladesh Agricultural Research Institute, Gazipur, regarded as non-polluted area. The spice samples represent individual and whole parts of the selected plants of onion, garlic and chilli (fruits, bulb, leaves-stems and roots). Soil samples from the above mentioned areas were collected from rhizosphere zone of the respective plants $(0-15 \mathrm{~cm})$ with a stainless steel auger during plant sampling.

\subsection{Preparation of plant and soil samples for analysis of heavy metals}

All spice samples were washed with running tap water then washed with deionized water. Clean samples were air-dried and placed in an electric 
oven at $65^{\circ} \mathrm{C}$ for $72-96 \mathrm{~h}$ depending on the sample size (Naser et al., 2012). Dried samples were homogenized by grinding using a ceramic coated grinder and used for heavy metal analysis. Soil samples were spread on plastic trays, dried at ambient temperature for 8 days. The samples were ground with a ceramic coated grinder and sieved through a nylon sieve (10 mesh) and kept in labeled polypropylene containers at ambient temperature before analysis.

\subsection{Digestion of samples}

One gram (1 g) of sample (soil/spice) was digested with $\mathrm{HNO}_{3}$ and $\mathrm{HClO}_{4}$ (5:1 volume) for total heavy metal determination as described by (Misra and Chaturvedi, 2007). Digestion was performed at temperature of about $190{ }^{\circ} \mathrm{C}$ for 1.5 h. After cooling, the samples were transferred into $50 \mathrm{ml}$ volumetric flask and solution was made up to a final volume raised up to the mark with distilled water.

\subsection{Determination of heavy metals and statistical analysis}

The heavy metal concentrations such as $\mathrm{Pb}, \mathrm{Cd}$, and $\mathrm{Ni}$ were determined by atomic absorption spectrophotometer (VARIAN model AA2407). Each sample was analyzed three times to obtain representative results and the data reported in $\mu \mathrm{g}$ $\mathrm{g}^{-1}$ (on a dry matter basis). Statistical analysis were performed by Tukey's multiple comparisons test by using Excel Statistics version 4.0 (Esumi Co. Ltd., Tokyo, Japan).

\section{Results and Discussion}

The mean values of $\mathrm{Pb}, \mathrm{Cd}$, and $\mathrm{Ni}$ content in plants (onion, garlic and chilli) and soils are shown in Tables 1-4, respectively. The levels of heavy metal content obtained in three spices and three soil samples from the polluted area (either directly or indirectly) were significantly higher than the non-polluted area. Numerous studies have also suggested that plants grown in polluted areas have higher concentrations of heavy metals than those grown in non-polluted area (Alam et al., 2003; Alegría et al., 1991; Arora et al., 2008;
Guttormsen et al., 1995; Dowdy and Larson, (1975).

Statistical significant difference $(P \leq 0.01)$ on heavy metals accumulation was noticed in polluted (either directly or indirectly) and nonpolluted areas in both spices and soils. There were significant differences in $\mathrm{Pb}, \mathrm{Cd}$, and $\mathrm{Ni}$ concentrations ( $\mu \mathrm{g} \mathrm{g}^{-1}$ of dry wt.) of different species (onion, garlic, and chilli) from different locations. A similar trend of heavy metals was observed in all spices. The metal contents in spices were monitored in the order of $\mathrm{Ni}>\mathrm{Pb}>\mathrm{Cd}$ and the degrees of soils pollution were directly polluted $>$ indirectly polluted $>$ non-polluted areas. The lead content was the highest in garlic with a range of 1.79 to 9.91 followed by chilli with a range of 2.93 to 5.55 and onion with a range of 1.0 to $4.59 \mu \mathrm{g} \mathrm{g}^{-1}$ of dry wt. in non polluted to polluted area. In the directly polluted area, $\mathrm{Ni}$ ( $\mu \mathrm{g} \mathrm{g}^{-1}$ of dry wt.) was the highest in garlic followed by onion and chilli i.e. garlic>onion>chilli. Lead, $\mathrm{Cd}$ and $\mathrm{Ni}$ concentrations in soils samples were also followed the similar trend as spices (Table 4).

Tables 1-3 showed the metal partitioning in plant tissues. Lead $(\mathrm{Pb}), \mathrm{Cd}$ and $\mathrm{Ni}$ concentrations in bulb/fruit, leaf and root of onion, garlic and chilli were increased significantly with the increase of total metal concentrations in soil. Of the total uptake, the highest $\mathrm{Pb}$ concentration was found in bulbs ranged from $38-41 \%$ followed by $32-$ $34 \%$ in roots and $25-27 \%$ in leaves, whereas $\mathrm{Ni}$ was found $57-62 \%$ in roots, $18-25 \%$ in leaves and $14-22 \%$ in bulbs/fruits. Lead and $\mathrm{Cd}$ concentrations can be categorized in the order of bulbs $>$ roots $>$ leaves. These result suggested that regardless of the degrees of pollution, most of the metals accumulated in bulb/fruit, moderate in root and the smallest amount in the leaf, except $\mathrm{Cd}$. The degrees of $\mathrm{Cd}$ concentration were found in the order of roots>leaves>bulbs/fruits. Partitioning of heavy metals in plant parts depends on several factors such as plant type, root system, variety, concentrations of heavy metals in the soils and the nature and properties of the soil (Arora et al., 2008; Naser et al., 
2012). It was reported that most of plants retain more than $50 \%$ of the absorbed cadmium in the roots than the storage organs or fruit (Obata and Umebayashi, 1993).

Average $\mathrm{Pb}$ content in the tested spices was $1.00-6.91 \mu \mathrm{g} \mathrm{g}^{-1}$ dry wt. which was lower than the values reported in Titagarh (21.59-57.63 $\mu \mathrm{g}$ $\mathrm{g}^{-1}$ dry wt), West Bengal (Gupta et al., 2008) and in Varanasi (3.09-15.74 $\mu \mathrm{g} \mathrm{g}^{-1}$ dry wt), India (Sharma et al., 2007) and 1.97-3.81 $\mu \mathrm{g} \mathrm{g}^{-1}$ dry wt in China (Liu et al., 2005). Furthermore, mean concentration of $\mathrm{Pb}$ was also lower than the vegetables (11.97-22.09 $\mu \mathrm{g} \mathrm{g}^{-1}$ dry wt) grown around the Dhaka Export Processing Zone (DEPZ), Bangladesh (Ahmed and Goni, 2009).

The mean Cd level (0.67-1.64 $\mu \mathrm{g} \mathrm{g}^{-1}$ dry wt) in spices grown in polluted (either directly or indirectly) areas was lower than the vegetables grown in DEPZ area of Dhaka (2.05-2.91 $\mu \mathrm{g} \mathrm{g}^{-1}$ dry wt), Titagarh, West Bengal, India (10.37$17.79 \mu \mathrm{g} \mathrm{g}^{-1}$ dry wt) (Gupta et al., 2008) and the vegetables from endemic upper gastrointestinal cancer region of Turkey $\left(25 \mu \mathrm{g} \mathrm{g}^{-1}\right.$ dry wt) (Türkdoğan et al., 2002). But it was higher or statistically similar than the vegetables from China (0.03-0.73 $\mathrm{gg} \mathrm{g}^{-1}$ dry wt) (Liu et al., 2005), and also significantly higher than the vegetables from Egypt (0.002-0.08 $\mu \mathrm{g} \mathrm{g}^{-1}$ dry wt) (Dogheim et al., 2004).

The amount of Ni (Tables 1-4) in both soil and spices samples was higher than $\mathrm{Pb}$ and $\mathrm{Cd}$ in all samples in studied areas. $\mathrm{Ni}$ concentration in edible vegetables was higher in polluted area than non-polluted area reported by Yusuf et al. (2003).

Table 1. Lead, $\mathrm{Cd}$ and Ni concentrations mean ( \pm , standard deviation) of onion grown on different polluted areas.

\begin{tabular}{|c|c|c|c|}
\hline \multirow{2}{*}{ Location } & \multicolumn{3}{|c|}{ Roots ( $\mu \mathrm{g} \mathrm{g}^{-1}$ of dry wt.) } \\
\hline & $\mathbf{P b}$ & Cd & $\mathbf{N i}$ \\
\hline Direct pollution & $3.86 \pm 0.29 a$ & $1.30 \pm 0.42 \mathrm{a}$ & $53.0 \pm 5.50 \mathrm{a}$ \\
\hline Indirect pollution & $3.32 \pm 0.20 \mathrm{a}$ & $0.90 \pm 0.07 b$ & $45.0 \pm 4.19 b$ \\
\hline Non pollution & $1.26 \pm 0.13 b$ & $0.66 \pm 0.10 \mathrm{c}$ & $12.3 \pm 0.72 \mathrm{c}$ \\
\hline \multirow[t]{2}{*}{ Location } & \multicolumn{3}{|c|}{ Bulb ( $\mu \mathrm{g} \mathrm{g}^{-1}$ of dry wt.) } \\
\hline & $\mathbf{P b}$ & Cd & $\mathbf{N i}$ \\
\hline Direct pollution & $6.42 \pm 0.32 \mathrm{a}$ & $1.62 \pm 0.13 a$ & $12.7 \pm 2.01 \mathrm{a}$ \\
\hline Indirect pollution & $3.62 \pm 0.19 b$ & $1.10 \pm 0.08 \mathrm{a}$ & $7.92 \pm 2.36 b$ \\
\hline Non pollution & $1.20 \pm 0.15 \mathrm{c}$ & $0.60 \pm 0.18 \mathrm{~b}$ & $3.18 \pm 0.35 c$ \\
\hline \multirow[t]{2}{*}{ Location } & \multicolumn{3}{|c|}{ Leaves ( $\mu \mathrm{g} \mathrm{g}^{-1}$ of dry wt.) } \\
\hline & $\mathbf{P b}$ & Cd & Ni \\
\hline Direct pollution & $3.50 \pm 0.24 a$ & $1.08 \pm 0.17 \mathrm{a}$ & $34.6 \pm 4.04 a$ \\
\hline Indirect pollution & $3.20 \pm 0.21 \mathrm{a}$ & $1.02 \pm 0.05 a$ & $5.70 \pm 1.95 b$ \\
\hline Non pollution & $0.54 \pm 0.14 b$ & $0.76 \pm 0.10 \mathrm{~b}$ & $6.54 \pm 0.55 b$ \\
\hline \multirow[t]{2}{*}{ Location } & \multicolumn{3}{|c|}{ Total plant $\left(\mu \mathrm{g} \mathrm{g}^{-1}\right.$ of dry wt.) } \\
\hline & $\mathbf{P b}$ & Cd & $\mathbf{N i}$ \\
\hline Direct pollution & $4.59 \pm 1.24 a$ & $4.59 \pm 1.24 a$ & $4.59 \pm 1.24 \mathrm{a}$ \\
\hline Indirect pollution & $3.38 \pm 0.75 b$ & $3.38 \pm 0.75 b$ & $3.38 \pm 0.75 b$ \\
\hline Non pollution & $1.00 \pm 0.21 \mathrm{c}$ & $1.00 \pm 0.21 \mathrm{c}$ & $1.00 \pm 0.21 \mathrm{c}$ \\
\hline Safe Limit ${ }^{\mathrm{a}}$ & 5 & 0.3 & 20 \\
\hline Safe Limit ${ }^{\mathrm{b}}$ & 2.5 & 1.5 & 1.5 \\
\hline
\end{tabular}

Mean values in the same column followed by the same letters are not significantly different $(P<0.01)$

${ }^{\mathrm{a}}$ [FAO/WHO - Codex Alimentarious Commission (1984)], ${ }^{\mathrm{b}}$ [Awashthi, 2000]. 
Table 2. Lead, Cd and Ni concentrations mean ( \pm , standard deviation) of garlic grown on different polluted areas.

\begin{tabular}{|c|c|c|c|}
\hline \multirow{2}{*}{ Location } & \multicolumn{3}{|c|}{ Roots ( $\mu \mathrm{g} \mathrm{g}^{-1}$ of dry wt.) } \\
\hline & $\mathbf{P b}$ & Cd & $\mathbf{N i}$ \\
\hline Direct pollution & $6.66 \pm 1.42 \mathrm{a}$ & $1.50 \pm 0.47 \mathrm{a}$ & $53.8 \pm 3.22 \mathrm{a}$ \\
\hline Indirect pollution & $4.32 \pm 0.89 b$ & $0.99 \pm 0.08 b$ & $27.7 \pm 3.01 b$ \\
\hline Non-pollution & $1.74 \pm 0.32 \mathrm{c}$ & $0.74 \pm 0.05 c$ & $11.3 \pm 1.58 \mathrm{c}$ \\
\hline \multirow{2}{*}{ Location } & \multicolumn{3}{|c|}{ Bulb ( $\mu \mathrm{g} \mathrm{g}^{-1}$ of dry wt.) } \\
\hline & $\mathbf{P b}$ & $\mathrm{Cd}$ & $\mathbf{N i}$ \\
\hline Direct pollution & $7.54 \pm 0.54 a$ & $1.80 \pm 0.66 a$ & $16.3 \pm 2.54 a$ \\
\hline Indirect pollution & $5.28 \pm 0.42 b$ & $0.84 \pm 0.07 b$ & $7.08 \pm 1.01 b$ \\
\hline Non-pollution & $2.64 \pm 1.12 \mathrm{c}$ & $0.64 \pm 0.09 b$ & $6.42 \pm 1.49 b$ \\
\hline \multirow{2}{*}{ Location } & \multicolumn{3}{|c|}{ Leaves ( $\mu \mathrm{g} \mathrm{g}^{-1}$ of dry wt.) } \\
\hline & $\mathbf{P b}$ & Cd & $\mathbf{N i}$ \\
\hline Direct pollution & $6.54 \pm 1.28 \mathrm{a}$ & $1.62 \pm 0.34 \mathrm{a}$ & $35.2 \pm 3.12 \mathrm{a}$ \\
\hline Indirect pollution & $4.38 \pm 1.78 b$ & $0.90 \pm 0.06 b$ & $5.16 \pm 1.29 b$ \\
\hline Non-pollution & $1.00 \pm 0.33 c$ & $0.70 \pm 0.05 b$ & $4.46 \pm 0.37 \mathrm{c}$ \\
\hline \multirow{2}{*}{ Location } & \multicolumn{3}{|c|}{ Total plant ( $\mu \mathrm{g} \mathrm{g}^{-1}$ of dry wt.) } \\
\hline & $\mathbf{P b}$ & Cd & $\mathbf{N i}$ \\
\hline Direct pollution & $4.59 \pm 1.07 \mathrm{a}$ & $1.64 \pm 0.23 a$ & $35.09 \pm 4.24 \mathrm{a}$ \\
\hline Indirect pollution & $3.38 \pm 0.53 b$ & $0.91 \pm 0.19 b$ & $13.3 \pm 2.04 b$ \\
\hline Non-pollution & $1.00 \pm 0.07 \mathrm{c}$ & $0.69 \pm 0.07 c$ & $7.37 \pm 0.70 c$ \\
\hline Safe Limit ${ }^{a}$ & 5 & 0.3 & 20 \\
\hline Safe Limit ${ }^{b}$ & 2.5 & 1.5 & 1.5 \\
\hline
\end{tabular}

Mean values in the same column followed by the same letters are not significantly different $(P<0.01)$

${ }^{\mathrm{a}}$ [FAO/WHO - Codex Alimentarious Commission (1984)], ${ }^{\mathrm{b}}$ [Awashthi, 2000].

Average Ni concentrations in spices varied from 5.2 - $35.1 \mu \mathrm{g} \mathrm{g}^{-1}$ dry wt. which were higher than the vegetables grown in DEPZ area of Dhaka (4.62-23.68 $\mu \mathrm{g} \mathrm{g}^{-1}$ dry wt.), Varanasi, India (1.81-7.57 $\mu \mathrm{g} \mathrm{g}^{-1}$ dry wt.) (Sharma et al., 2007) and in Delhi, India (8.78 -21.5 $\mu \mathrm{g} \mathrm{g}^{-1}$ dry wt.) (Rattan et al., 2005).

The concentrations of $\mathrm{Pb}, \mathrm{Cd}$ and $\mathrm{Ni}$ were higher in edible plant parts collected from directly polluted area than indirectly polluted and nonpolluted areas of Gazipur city in Bangladesh. However, these concentrations were much higher than the permissible limit recommended by India (Awashthi, 2000), FAO/WHO (1984) and China (SEPA 2005). The maximum $\mathrm{Pb}$ was found in garlic (6.91 $\mu \mathrm{g} \mathrm{g}^{-1}$ dry wt.) followed by chilli
(5.55 $\mu \mathrm{g} \mathrm{g}^{-1}$ dry wt.) from directly polluted area which exceeded the acceptable tolerance limit proposed by Indian standard (Awashthi 2000). In directly polluted area, $\mathrm{Cd}$ accumulation was higher in garlic (1.64 $\mu \mathrm{g} \mathrm{g}^{-1}$ dry wt.) followed by chilli (1.49 $\mu \mathrm{g} \mathrm{g}^{-1}$ dry wt.) which also exceeded the acceptable tolerance limit recommended by FAO/WHO (1984). Maximum Ni was detected in garlic (35.1 $\mathrm{\mu g} \mathrm{g}^{-1}$ dry wt.) which is 2,23 and 4-fold higher than the recommended limit of FAO/WHO (1984), India (Awashthi 2000) and of China (SEPA, 2005). However, $\mathrm{Pb}$ and $\mathrm{Cd}$ concentrations in non-polluted area were lower than the permissible limit recommended by FAO/WHO (1984), India (Awashthi, 2000) and China (SEPA 2005). 
Table 3. Lead, Cd and Ni concentrations mean ( \pm , standard deviation) of chilli grown on different polluted areas.

\begin{tabular}{|c|c|c|c|}
\hline \multirow{2}{*}{ Location } & \multicolumn{3}{|c|}{ Roots ( $\mu \mathrm{g} \mathrm{g}^{-1}$ of dry wt.) } \\
\hline & $\mathbf{P b}$ & Cd & $\mathrm{Ni}$ \\
\hline Direct pollution & $5.36 \pm 1.32 \mathrm{a}$ & $1.56 \pm 0.64 \mathrm{a}$ & $61.8 \pm 3.12 \mathrm{a}$ \\
\hline Indirect pollution & $4.58 \pm 1.24 b$ & $0.99 \pm 0.07 b$ & $42.5 \pm 3.18 b$ \\
\hline Non-pollution & $3.08 \pm 0.44 \mathrm{c}$ & $0.80 \pm 0.05 b$ & $7.86 \pm 0.82 c$ \\
\hline \multirow{2}{*}{ Location } & \multicolumn{3}{|c|}{ Fruit ( $\mu \mathrm{g} \mathrm{g}^{-1}$ of dry wt.) } \\
\hline & $\mathbf{P b}$ & Cd & $\mathbf{N i}$ \\
\hline Direct pollution & $6.10 \pm 1.40 \mathrm{a}$ & $1.50 \pm 0.25 \mathrm{a}$ & $21.4 \pm 2.38 \mathrm{a}$ \\
\hline Indirect pollution & $5.26 \pm 1.09 b$ & $1.20 \pm 0.10 \mathrm{a}$ & $11.3 \pm 1.78 b$ \\
\hline Non-pollution & $3.38 \pm 0.99 \mathrm{c}$ & $0.82 \pm 0.13 b$ & $4.14 \pm 0.62 \mathrm{c}$ \\
\hline \multirow{2}{*}{ Location } & \multicolumn{3}{|c|}{ Leaves ( $\mu \mathrm{g} \mathrm{g}^{-1}$ of dry wt.) } \\
\hline & $\mathbf{P b}$ & Cd & $\mathbf{N i}$ \\
\hline Direct pollution & $5.18 \pm 1.72 \mathrm{a}$ & $1.40 \pm 0.50 \mathrm{a}$ & $15.2 \pm 2.47 \mathrm{a}$ \\
\hline Indirect pollution & $3.86 \pm 0.45 b$ & $0.80 \pm 0.07 b$ & $8.82 \pm 2.44 b$ \\
\hline Non-pollution & $2.32 \pm 0.66 \mathrm{c}$ & $0.66 \pm 0.09 b$ & $3.72 \pm 0.35 c$ \\
\hline \multirow{2}{*}{ Location } & \multicolumn{3}{|c|}{ Total plant ( $\mu \mathrm{g} \mathrm{g}^{-1}$ of dry wt.) } \\
\hline & $\mathbf{P b}$ & Cd & $\mathbf{N i}$ \\
\hline Direct pollution & $5.55 \pm 0.55 a$ & $1.49 \pm 0.31 \mathrm{a}$ & $32.8 \pm 4.37 \mathrm{a}$ \\
\hline Indirect pollution & $4.57 \pm 1.04 \mathrm{~b}$ & $1.01 \pm 0.40 b$ & $20.9 \pm 2.07 b$ \\
\hline Non-pollution & $2.93 \pm 0.52 c$ & $0.76 \pm 0.07 \mathrm{c}$ & $5.24 \pm 1.47 \mathrm{c}$ \\
\hline Safe Limit ${ }^{\mathrm{a}}$ & 5 & 0.3 & 20 \\
\hline Safe Limit ${ }^{b}$ & 2.5 & 1.5 & 1.5 \\
\hline
\end{tabular}

Mean values in the same column followed by the same letters are not significantly different $(P<0.01)$

a [FAO/WHO - Codex Alimentarious Commission (1984)], ${ }^{\mathrm{b}}$ [Awashthi, 2000].

The concentrations of metals found in soil of the polluted areas in the present investigation was lower than the permissible limits reported by Awashthi (2000); Bowen (1966, except Ni); Kabata-Pendias and Pendias (1992, except Ni); Temmerman et al. (1984, except $\mathrm{Cd}$ and $\mathrm{Ni})$.

High concentrations of heavy metals in the polluted areas might be due to high contents of metals in the soil as caused by irrigation with metal contaminated water released from different kinds of industries. The river Turag is highly polluted by industrial effluents, sewage sludge, municipal waste water and urban pollution. Comparatively, lower concentration of heavy metals were found in spices grown in indirectly polluted area (Dhonkar bill) might be due to the pattern of contamination, where ponds and canals contaminated water submerged the adjacent cultivable land during rainy season after that the farmers grown their crops in winter. However, the higher concentrations of $\mathrm{Pb}, \mathrm{Cd}$ and $\mathrm{Ni}$ were found in the polluted (either directly or indirectly) area indicate that different types of industrial activities such as textiles, paints, battery, milling and chemical industries may contaminate or introduce heavy metals into the soil.

\section{Conclusions}

The higher amount of $\mathrm{Pb}, \mathrm{Cd}$ and $\mathrm{Ni}$ were found in both soils and spices samples collected in and around industrial areas of Gazipur city in Bangladesh. All the spices contained heavy metals higher than the recommended tolerance levels proposed by FAO/WHO and SEPA. Thus, the authors strongly recommended, not to grow spices in industrial polluted areas of Bangladesh to prevent the excessive build up of heavy metals in the food chain. 
Table 4. Lead, $\mathrm{Cd}$, and $\mathrm{Ni}$ concentrations mean ( \pm , standard deviation) of rizospheric soils of three spices $\left(\mu \mathrm{g} \mathrm{g}^{-1}\right.$ of dry wt.) from different polluted areas.

\begin{tabular}{|c|c|c|c|}
\hline \multirow{2}{*}{ Location } & \multicolumn{3}{|c|}{ Onion } \\
\hline & $\mathbf{P b}$ & Cd & $\mathbf{N i}$ \\
\hline Direct pollution & $21.2 \pm 2.88 \mathrm{a}$ & $2.70 \pm 1.44 \mathrm{a}$ & $39.2 \pm 2.83 a$ \\
\hline Indirect pollution & $16.8 \pm 1.53 b$ & $1.70 \pm 0.21 b$ & $36.6 \pm 1.11 b$ \\
\hline Non-pollution & $5.28 \pm 0.78 c$ & $0.90 \pm 0.14 c$ & $15.8 \pm 1.60 \mathrm{c}$ \\
\hline \multirow{2}{*}{ Location } & \multicolumn{3}{|c|}{ Garlic } \\
\hline & $\mathbf{P b}$ & Cd & $\mathbf{N i}$ \\
\hline Direct pollution & $18.4 \pm 2.07 \mathrm{a}$ & $2.20 \pm 0.15 a$ & $40.5 \pm 3.55 a$ \\
\hline Indirect pollution & $17.4 \pm 1.44 \mathrm{a}$ & $1.90 \pm 0.08 b$ & $38.7 \pm 3.12 \mathrm{a}$ \\
\hline Non-pollution & $4.84 \pm 1.01 \mathrm{~b}$ & $0.70 \pm 0.07 \mathrm{c}$ & $14.6 \pm 1.57 \mathrm{~b}$ \\
\hline \multirow{2}{*}{ Location } & \multicolumn{3}{|c|}{ Chili } \\
\hline & $\mathbf{P b}$ & $\mathbf{C d}$ & $\mathbf{N i}$ \\
\hline Direct pollution & $22.2 \pm 2.13 a$ & $2.50 \pm 0.78 \mathrm{a}$ & $38.6 \pm 3.47 \mathrm{a}$ \\
\hline Indirect pollution & $18.4 \pm 2.74 b$ & $1.80 \pm 0.47 b$ & $35.6 \pm 2.37 \mathrm{a}$ \\
\hline Non-pollution & $6.72 \pm 1.11 \mathrm{c}$ & $0.80 \pm 0.13 c$ & $15.8 \pm 2.37 b$ \\
\hline Safe Limit ${ }^{\mathrm{a}}$ & $250-500$ & $3-6$ & $75-150$ \\
\hline Safe Limit ${ }^{b}$ & 100 & 3 & 50 \\
\hline Safe Limit ${ }^{c}$ & 100 & 5 & 100 \\
\hline
\end{tabular}

Mean values in the same column followed by the same letters are not significantly different $(P<0.01)$

${ }^{\mathrm{a}}$ [Awashthi, 2000], ${ }^{\mathrm{b}}$ [Ewers, 1991]. ${ }^{\mathrm{c}}$ [Kabata-Pendias and Pendias, 1992].

\section{References}

Ahmed, J. U., and Goni, M. A. 2010. Heavy metal contamination in water, soil, and vegetables of the industrial areas in Dhaka, Bangladesh. Environmental Monitoring and Assessment, 166: 347-357.

Alam, M. G. M., Snow, E.T. and Tanaka, A. 2003. Arsenic and heavy metal contamination of vegetables grown in Samta village, Bangladesh. The Science of The Total Environment, 308: 83-96.

Alegría, A., Barberá, R. Boluda, R., Errecalde, R. Farré, R. and Lagarda, M. J. 1991. Environmental cadmium, lead and nickel contamination: possible relationship between soil and vegetable content. Fresenius' Journal of Analytical Chemistry, 339: 654-657.

Arora, M., Kiran, B., Rani, S., Rani, A., Kaur, B. and Mittal, N. 2008. Heavy metal accumulation in vegetables irrigated with water from different sources. Food Chemistry, 111: 811-815.

Awashthi, S. K. 2000. Prevention of Food Adulteration Act No. 37 of 1954. Central and State rules as amended for 1999 (3rd ed.). New Delhi: Ashoka Law House, India.

Bahemuka, T. E. and Mubofu, E. B. 1991. Heavy metals in edible green vegetables grown along the sites of the Sinza and Msimbazi rivers in Dar es Salaam, Tanzania. Food Chemistry, 66: 63-66.

Bowen, H. J. M. 1966. Trace elements in biochemistry. Academic Press. Science, $241 \mathrm{p}$.

Bruemmer, G.W., Gerth, J. and Herms, U. 1986. Heavy metal species, mobility and availability in soils. Zeitschrift für Pflanzenernährung und Bodenkunde, 149: 382-398. 
Dogheim, S. M., Ashraf, El. M. M., Alla, S. A. G., Khorshid, M. A. and Fahmy, S. M. 2004. Pesticides and heavy metals levels in Egyptian leafy vegetables and some aromatic medicinal plants. Food Additives and Contaminants, 21: 323-330.

Dowdy, R. H. and Larson, W. E. 1975. Metal uptake by barley seedlings grown on soils amended with sewage sludge. Journal of Environmental Quality, 4: 278-283.

Ewers, U. 1991. Standards, guidelines and legislative regulations concerning metals and their compounds. In: Merian E, ed. Metals and Their Compounds in the Environment: Occurrence, Analysis and Biological Relevance. Weinheim: VCH, 458-468 pp.

FAO/WHO - Codex Alimentarious Commission (1984) Contaminants, Joint FAO/WHO Food standards Program (Vol. XVII, 1st ed.). Geneva: Codex Alimentarious.

Gupta, N., Khan, D. K. and Santra, S. C. 2008. An assessment of heavy metal contamination in vegetables grown in wastewater-irrigated areas of Titagarh, West Bengal, India. Bulletin of Environmental Contamination and Toxicology, 80: 115-118.

Guttormsen, G, Singh, B. R. and Jeng, A. S. 1995. Cadmium concentration in vegetable crops grown in a sandy soil as affected by Cd levels in fertilizer and soil pH. Fertilizer Research, 41: 27-32.

Jarup, L. 2003. Hazards of heavy metal contamination. British Medical Journal, 68: 167-182.

Kabata-Pendias, A. and Pendias, H. 1992. Trace elements in soil and plants (2nd ed., p. 365). Boca Raton: CRC Press.

Khan, S., Cao, Q., Zheng, Y. M., Huang, Y. Z. and Zhu, Y. G. 2008. Health risks of heavy metals in contaminated soils and food crops irrigated with wastewater in
Beijing, China. Environmental Pollution, 152: 686-692.

Liu, W. H., Zhao, J. Z., Ouyang, Z. Y., Soderlund, L. and Liu, G. H. 2005. Impacts of sewage irrigation on heavy metals distribution and contamination. Environment International. 31: 805-812.

Ma, Q. Y., Traina, S. J. and Logan, T. J. 1994. Effect of aqueous $\mathrm{Al}, \mathrm{Cd}, \mathrm{Fe}(\mathrm{II}), \mathrm{Ni}$ and $\mathrm{Zn}$ on $\mathrm{Pb}$ immobilization by hydroxyapatite. Environmental Science and Technology, 28:1219-1228.

Mahmood, A. and Malik, R. N. 2014. Human health risk assessment of heavy metals via consumption of contaminated vegetables collected from different irrigation sources in Lahore, Pakistan. Arabian Journal of Chemistry, 7: 91-99.

Mapanda, F., Mangwayana, E. N., Nyamangara, J. and Giller, K. E. 2005. The effects of long-term irrigation using water on heavy metal contents of soils under vegetables. Agriculture, Ecosystem and Environment, 107: 151-156.

Mattioni, C., Gabrielli, R., Vangrousveld, J. V. and Clijsters, H. 1997. Nickel and cadmium toxicity and enzymatic activity in nitolerant and non-tolerant populations of Silene italica Pers. Journal of Plant Physiology, 150: 173-177.

McBride, M. B. 2003. 'Toxic metals in sewage sludge-amended soils: has promotion of beneficial use discounted the risks?' Advances in Environmental Research, 8:5-19.

Mingorance, M. D., Valdes, B. and Oliva R. S. 2007. Strategies of heavy metal uptake by plants growing under industrial emissions. Environment International, 33: 514-520.

Misra, V. and Chaturvedi P. K. 2007. Plant uptake/bioavailability of heavy metals from the contaminated soil after treatment with humus soil and hydroxyapatite. 
Environmental Monitoring and Assessment, 133:169-176.

Naser, H. M., Mahmud, N, U., Sultana, S., Gomes. R., and Rahman, R. 2012. Trace elements content in vegetables grown in industrially polluted and non-polluted areas. Bangladesh Journal of Agricultural Research, 37: 515-527.

Obata, H., Umebayashi, M., 1993. Production of $\mathrm{SH}$ compounds in higher plants of different tolerance to Cd. Plant and Soil, 155/156: 533-536.

Rattan, R. K., Datta, S. P., Chhonkar, P. K., Suribabu, K. and Singh, A. K. 2005. Longterm impact of irrigation with sewage effluents on heavy metal contents in soils, crops and ground water - a case study. Agriculture, Ecosystem and Environment, 109: 310-322.

Roy, R., Fakhruddin, A. N. M., Khatun, R., Islam, M. S., Ahsan, M. A., and Neger, A. J. M. T. 2009. Characterization of textile industrial effluents and its effects on aquatic macrophytes and algae. Bangladesh Journal of Science and Industrial Research, 45: 79-84.

Singh, B. 2001. 'Heavy metals in soils: sources, chemical reactions and forms', in: Smith, D., Fityu, S. and Allman M. (eds.), Geotechnics: Proceedings of the 2nd Australia and New Zealand Conference on Environmental Geotechnics, Newcastle, NSW, Australia, November 2001, 77-93 pp.
State Environmental Protection Administration (SEPA), 2005. The limits of pollutant in food. State Environmental Protection Administration. China. GB 2762-2005. Environmental Pollution, Series B (4): 281-290.

Sharma, R. K., Agrawal, M. and Marshall, F. 2007. Heavy metal contamination of soil and vegetables in suburban areas of Varanasi, India. Ecotoxicology and Environmental Safety, 66: 258-266.

Temmerman, L. O., Hoeing, M. and Scokart, P. O. 1984. Determination of "normal" levels and upper limit values of trace elements in soils. Zeitschrift für Pflanzenernährung und Bodenkunde, 147: 687-694.

Türkdoğan, M. K., Killicel, F., Kara, K., Tuncer, I. and Uygan, I. 2002. Heavy metals in soil, vegetables and fruits in the endemic upper gastrointestinal cancer region of Turkey. Environmental Toxicology and Pharmacology, 13: 175-179.

Yusuf, A. A., Arowolo, T. A. and Bamgbose, O. 2003. Cadmium, copper and nickel levels in vegetables from industrial and residential areas of Lagos City, Nigeria. Food and Chemical Toxicology, 41: 375378.

Whatmuff, M. S. 2002. 'Applying biosolids to acid soil in New SouthWales: Are guideline soil metal limits from other countries appropriate?' Australian Journal of Soil Research, 40: 1041-1056. 